\title{
ECONOMIC EVALUATION OF LETTUCE FERTILIZED WITH BIOMASS OF Calotropis procera IN TWO GROWING SEASONS ${ }^{1}$
}

\author{
ÊNIO GOMES FLÔR SOUZA ${ }^{*}$, FALKNER MICHAEL DE SOUSA SANTANA ${ }^{3}$, BRUNO NOVAES MENEZES \\ MARTINS $^{4}$, YGOR HENRIQUE LEAL ${ }^{5}$, AURÉLIO PAES BARROS JÚNIOR ${ }^{6}$, LINDOMAR MARIA DA SILVEIRA ${ }^{6}$
}

\begin{abstract}
Vegetable production is an impactful activity, characterized by intensive land use, high input demand, and it requires strategic management adoption, especially in sustainable production systems, where the pillars of sustainability (environmental, social and economic) must be respected. In this sense, the objective of this work was to evaluate economic indicators of lettuce production using Caatinga spontaneous species (Calotropis procera: rooster tree) as fertilizer and cultivated in two seasons (spring and fall-winter) in the municipality of Serra Talhada, PE. The experimental design was in randomized blocks, arranged in a $4 \mathrm{x} 4$ factorial scheme, with three replications. The first factor was the biomass amounts of green manure (5.4, 8.8, 12.2 and $15.6 \mathrm{t} \mathrm{ha}^{-1}$ on a dry basis); and the second was their incorporation times in the soil (0, 10, 20 and 30 days before lettuce transplanting). The green mass yield, production costs, rate of return, and net profit margin were determined. The amount $15.6 \mathrm{t} \mathrm{ha}^{-1}$ of $C$. procera allowed higher profitability to the organic production of lettuce, and it is considered ideal to incorporate the green manure 11 (spring) and 15 (fall-winter) days before transplanting the vegetable. The spring crop promoted a superior economic return to the fall-winter planting, demonstrating economic viability even in the smallest amount of $C$. procera.
\end{abstract}

Keywords: Lactuca sativa L. Rooster tree. Organic farming. Profitability.

\section{AVALIAÇÃO ECONÔMICA DA ALFACE ADUBADA COM BIOMASSA DE Calotropis procera EM DUAS ÉPOCAS DE CULTIVO}

\begin{abstract}
RESUMO - A produção de hortaliças é uma atividade impactante, que se caracteriza pelo uso intensivo do solo, alta demanda de insumos e requer adoção estratégica de manejo, sobretudo em sistemas de produção sustentável, em que os pilares da sustentabilidade (ambiental, social e econômico) devem ser respeitados. Neste sentido, o objetivo desse trabalho foi avaliar indicadores econômicos da produção de alface adubada com espécie espontânea da Caatinga (Calotropis procera: Flor-de-seda) e cultivada em duas épocas (primavera e outono-inverno), no município de Serra Talhada-PE. O delineamento experimental foi em blocos casualizados, com os tratamentos arranjados em esquema fatorial $4 \times 4$, com três repetições, sendo o primeiro fator: as quantidades de biomassa do adubo verde $\left(5,4 ; 8,8 ; 12,2\right.$ e $15,6 \mathrm{t} \mathrm{ha}^{-1}$ em base seca); e o segundo: seus tempos de incorporação ao solo $(0,10,20$ e 30 dias antes do transplantio da alface). Além do rendimento de massa verde e dos custos de produção, foram determinadas as rendas bruta e líquida, taxa de retorno e índice de lucratividade. A quantidade de 15,6 t ha ${ }^{-1}$ de $C$. procera possibilitou maior rentabilidade à produção orgânica de alface, sendo considerado ideal incorporar o adubo verde 11 (primavera) e 15 (outono-inverno) dias antes do transplantio da hortaliça. O cultivo de primavera promoveu retorno econômico superior ao plantio de outonoinverno, demonstrando viabilidade econômica mesmo na menor quantidade de C. procera.
\end{abstract}

Palavras-chave: Lactuca sativa L. Flor-de-seda. Cultivo orgânico. Lucro.

\footnotetext{
${ }^{*}$ Corresponding author

${ }^{1}$ Received for publication in $05 / 16 / 2017$; accepted in 01/22/2018.

${ }^{2}$ Agronomic Engineering Course, Instituto Federal de Educação, Ciência e Tecnologia de Alagoas, Piranhas, AL, Brazil; enio.souza@ifal.edu.br - ORCID: 0000-0003-4355-3388.

${ }^{3}$ Department of Plant Science, Universidade Federal do Ceará, Fortaleza, CE, Brazil; falkner.agro@hotmail.com - ORCID: 0000-00020680-3096.

${ }^{4}$ Department of Horticulture, Universidade Estadual Paulista, Botucatu, SP, Brazil; brunonovaes17@hotmail.com - ORCID: 0000-00022664-6817.

${ }^{5}$ Postgraduate Program in Agronomy, Universidade Federal da Paraíba, Areia, PB, Brazil; ygoragronomo@gmail.com - ORCID: 00000001-7155-3524.

${ }^{6}$ Center for Agrarian Sciences, Universidade Federal Rural do Semi-Árido, Mossoró, RN, Brazil; aurelio.barros@ufersa.edu.br - ORCID: 0000-0002-6983-8245, lindomarmaria@ufersa.edu.br - ORCID: 0000-0001-9719-7417.
} 


\section{INTRODUCTION}

Lettuce (Lactuca sativa $\mathrm{L}$.) is one of the most cultivated vegetables in Brazil, with great social, economic, and food importance. In Northeast Brazilian, lettuce presents cultivars adapted to the local climatic conditions: early cycle, low occurrence of pests and diseases, and good acceptance by the consumer market. In order to obtain quality products throughout the year, it is necessary to plan the plantation, mainly observing the microclimates of each region, the growing season of each variety, production costs, and other variables that would affect investment in the lettuce crop.

In the case of organic fertilizers, the soil is rich in nutrients, particularly in tropical soils, where the mineralization of the organic matter is intense (MONTEMURRO et al., 2010). The use of organic sources from the property itself is of fundamental importance for sustainable agricultural production systems. Green manure is a commonly used technique in cultivation, and it involves the incorporation of plant remains produced locally or added to preserve and/or restore soil organic matter and nutrient contents (OLIVEIRA et al., 2011).

Calotropis procera (Ait.) R. Br., popularly known as rooster tree, has been highlighted as a potential plant species for use as green manure in the production of vegetables (LINHARES et al., 2014; SOUZA et al., 2017). In addition to adding nitrogen (N) to the system, it improves the chemical, physical and biological characteristics of soils, thus contributing to the increase of soil biological diversity (ESPINDOLA; ALMEIDA; GUERRA, 2004; SOUZA et al., 2012). Considered a ruderal species, C. procera occupies areas modified by humans. However, due to its rapid development and easy dissemination, it is considered a dominant invasive plant in abandoned and/or physically and chemically degraded areas, serving as a species indicative of this type of disturbance (SOUTO et al., 2008; CEPAN, 2009).

The use of native or spontaneous species of the Caatinga biome as a source of green manure for the production of vegetables is of great importance. In this region, this segment of agriculture is mainly characterized as being practiced under family agriculture, and green manure may minimize the costs of production, since this input would be obtained from the property (LINHARES et al., 2009; LINHARES et al., 2014; OLIVEIRA et al., 2015; SOUZA et al., 2017; SILVA et al., 2017). According to Carvalho and Sabbag (2015), the hypothesis of evaluating efficiency in lettuce production allows mapping products with lower resource consumption, which can in turn lead to greater profitability for those who produce.

The objective of this work was to evaluate the economic viability of lettuce cultivation as a function of different amounts of $C$. procera biomass and their incorporation times in the soil, in two growing seasons (spring and fall-winter), under the conditions of Serra Talhada, Pernambuco.

\section{MATERIAL AND METHODS}

Two field experiments were conducted in two growing seasons: spring (September 16 to November 18, 2011) and fall-winter (May 20 to July 24, 2012), at the Federal Rural University of Pernambuco (UFRPE) Academic Unit of Serra Talhada (UAST), located at $7^{\circ} 57^{\prime} 15^{\prime \prime}$ South and $38^{\circ} 17^{\prime} 41^{\prime \prime}$ West, with a $461 \mathrm{~m}$ altitude, in the micro region of Sertão do Pajeú, north of Pernambuco. The average meteorological data of the period of the experiments are presented in Figure 1.

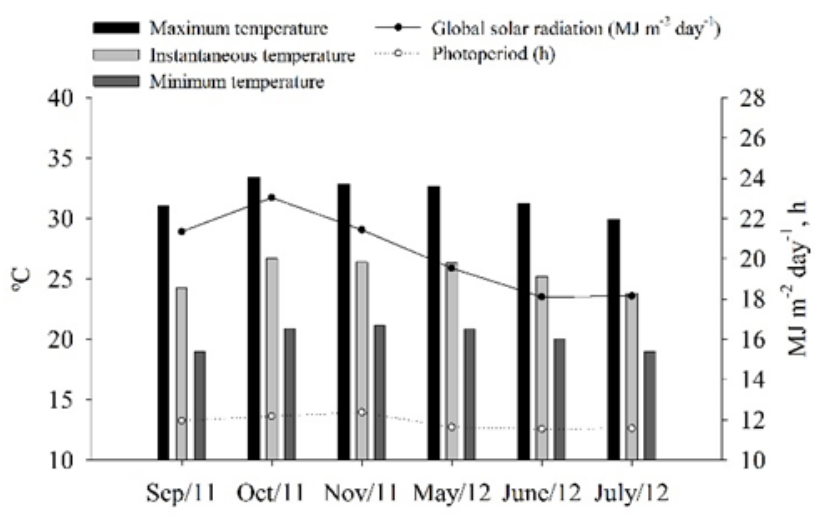

Figure 1. Mean monthly values of instantaneous, maximum and minimum temperatures, global solar radiation (MJ $\mathrm{m}^{-2} \mathrm{day}^{-}$ ${ }^{1}$ ) and photoperiod (h) in each season of lettuce cultivation fertilized with Calotropis procera.

The soil of the experimental area had a sandy loam texture, whose chemical characteristics, at the depth of $0-0.20 \mathrm{~m}$, before the installation of the experiments were as follows: in spring $-\mathrm{pH}$ in $\mathrm{H}_{2} \mathrm{O}$
$(1: 2.5)=7.2$; organic matter $(\mathrm{OM})=12.8 \mathrm{~g} \mathrm{~kg}^{-1} ; \mathrm{P}=$ $14.0 \mathrm{mg} \mathrm{dm} ; \mathrm{K}^{+}=0.5 \mathrm{cmol}_{\mathrm{c}} \mathrm{dm}^{-3} ; \mathrm{Ca}^{2+}=3.9 \mathrm{cmol}_{\mathrm{c}}$ $\mathrm{dm}^{-3} ; \mathrm{Mg}^{2+}=1.2 \mathrm{cmol}_{\mathrm{c}} \mathrm{dm}^{-3} ; \mathrm{Al}^{3+}=0.0 \mathrm{cmol}_{\mathrm{c}} \mathrm{dm}^{-3} ;$ and in fall-winter $-\mathrm{pH}$ in $\mathrm{H}_{2} \mathrm{O}(1: 2.5)=6.5 ; \mathrm{OM}=$ 
$12.7 \mathrm{~g} \mathrm{~kg}^{-1} ; \mathrm{P}=20.0 \mathrm{mg} \mathrm{dm}{ }^{-3} ; \mathrm{K}^{+}=0.4 \mathrm{cmol}_{\mathrm{c}} \mathrm{dm}^{-3}$; $\mathrm{Ca}^{2+}=3.4 \mathrm{cmol}_{\mathrm{c}} \mathrm{dm}^{-3} ; \mathrm{Mg}^{2+}=1.1 \mathrm{cmol}_{\mathrm{c}} \mathrm{dm}^{-3} ; \mathrm{Al}^{3+}=$ $0.0 \mathrm{cmol}_{\mathrm{c}} \mathrm{dm}^{-3}$ (SILVA, 2009).

The experimental design used in each experiment was a randomized complete block, with treatments arranged in a $4 \times 4$ factorial scheme, with three replications. The first factor being four biomass amounts of $C$. procera $\left(5.4,8.8,12.2\right.$ and $15.6 \mathrm{tha}^{-1}$ on a dry basis), and the second factor the four time periods of incorporating this fertilizer into the soil $(0$, 10, 20 and 30 days before lettuce transplanting).

Each experimental unit had a total area of $1.44 \mathrm{~m}^{2}$, with a useful plot of $0.64 \mathrm{~m}^{2}$. Six rows or planting lines were arranged transversely in each plot, spaced $0.20 \mathrm{~m}$ apart and within a line with 0.20 $\mathrm{m}$ between plants. The cultivar of planted lettuce was Babá-de-Verão, indicated for cultivation in the northeast region. Soil preparation in each experiment consisted of lifting the beds using hoes.

The $C$. procera was collected in localities near the UAST and then crushed in a conventional forage machine, obtaining fragments between two and three centimeters and set to dry until reaching hay condition ( $10 \%$ moisture). The material was analyzed and contained the following nutrient contents in dry matter: $\mathrm{N}=17.4 \mathrm{~g} \mathrm{~kg}^{-1} ; \mathrm{P}=4.4 \mathrm{~g} \mathrm{~kg}^{-}$ ${ }^{1} ; \mathrm{K}=23.5 \mathrm{~g} \mathrm{~kg}^{-1} ; \mathrm{Ca}=14.3 \mathrm{~g} \mathrm{~kg}^{-1} ; \mathrm{Mg}=23.0 \mathrm{~g} \mathrm{~kg}^{-}$ ${ }^{1} ; \mathrm{Fe}=463.0 \mathrm{mg} \mathrm{kg}^{-1}, \mathrm{Zn}=40.0 \mathrm{mg} \mathrm{kg}$; $\mathrm{Cu}=29.0$ $\mathrm{mg} \mathrm{kg}{ }^{-1} ; \mathrm{Mn}=90.0 \mathrm{mg} \mathrm{kg}^{-1} ; \mathrm{B}=71.0 \mathrm{mg} \mathrm{kg}{ }^{-1} ; \mathrm{Na}=$ $1,640.0 \mathrm{mg} \mathrm{kg}^{-1}, \mathrm{OM}=764.0 \mathrm{mg} \mathrm{kg}{ }^{-1} ; \mathrm{C} / \mathrm{N}=25 / 1$ (SILVA, 2009).

The incorporation of the vegetal biomass was carried out in the $0-0.20 \mathrm{~m}$ layer of the soil in the experimental plots, according to the treatments. Daily irrigations were carried out in two shifts with the purpose of favoring the microbial activity of the soil in the process of organic matter mineralization. This was done by a micro-sprinkler system, with daily irrigation in two applications (morning and afternoon), providing a water slide of approximately $8 \mathrm{~mm} \mathrm{day}^{-1}$ (MAROUELLI; SILVA; SILVA, 2008).

The production of lettuce seedlings was carried out in expanded polystyrene trays with 128 cells and use of the commercial substrate Plantmax HT®, housed in a $50 \%$ shade nursery. The planting of lettuce in the first growing season (spring) was carried out on September 20, 2011, while in fallwinter it was done on May 25, 2012. On October 16, 2011 (spring) and 19 June 2012 (fall-winter), after the last incorporation of the green manure into the soil, the lettuce seedlings were transplanted. Handwashing was performed whenever necessary.
In the spring, the lettuce harvest was performed 32 days after transplanting (DAT), while in fall-winter it was done 36 DAT. From the green mass yield ( $\mathrm{t} \mathrm{ha}{ }^{-1}$ ) obtained in the useful area, the yields for each experimental unit were estimated, considering the area effectively planted to $70 \%$. Economic indicators were used to evaluate the efficiency of treatments. Production costs were estimated, which were calculated and analyzed at the end of the production process. The cost modality analyzed in this work corresponded to the total expenditures per hectare of cultivated area, which include services provided by stable capital, i.e. the contribution of working capital and the value of alternative or opportunity costs. Similarly, the proceeds refer to the value of the production of one hectare.

The acquisition cost was obtained by multiplying the price of the variable input used (seeds, fertilizers, casual labor etc.) by the amount of the respective input, referring to the years 2011 (spring) and 2012 (fall-winter), to the city of Serra Talhada, PE. The cost of one ton of $C$. procera green manure was estimated for each quantity factor, quantifying the labor required for cutting, grinding, drying and bagging. The prices in force in the month of November 2011 for the first experiment and in the month of July 2012 for the second experiment in the same city were considered. The daily value paid to rural workers in the region was $\mathrm{R} \$ 25.00$ and $\mathrm{R} \$$ 30.00 for the first and second growing seasons, respectively. The cost of transporting the fertilizer after the cut was also calculated for each quantity ( $R \$ 75.00$ in the spring crop and $\mathrm{R} \$ 80.00$ in the fall -winter crop).

In this way, the final cost of each treatment was determined according to the different quantities incorporated, the time spent for incorporation (variable as a function of quantity) and other production costs. It should also be noted that the treatments corresponding to the incorporation periods $(0,10,20$ and 30 days) did not influence production costs. However, they participated in the combination of the factorial to determine the best economic efficiency in the cultivation of lettuce fertilized with $C$. procera.

Depreciation, defined as the non-monetary fixed cost that reflects the loss of value of a good of production as a function of age, use and obsolescence was determined by the linear method or fixed quota method, which determines the annual value of depreciation from the useful life of the durable good, its initial value and scrap. The latter was not considered, since the capital assets considered do not present any residual value. Taxes and fees, as well as fixed labor, were determined by the amount used in the current months to produce the 
crop. The fixed labor force was that dedicated to the management of productive activities, corresponding to the payment of the minimum wage each month during each productive cycle ( $\mathrm{R} \$ 545.00$ for the year 2011 and $\mathrm{R} \$ 622.00$ for 2012).

The opportunity cost for stable capital items (buildings, machines, equipment, etc.) corresponded to the annual interest that reflects the alternative use of capital. The chosen interest rate was $6 \%$ per annum, equivalent to the savings account gain. For the remuneration of fixed capital, the interest was on the current value throughout the crop. Concerning the opportunity cost of land, the lease of one hectare in the region ( $\mathrm{R} \$ 200.00$ ) was considered as the equivalent of the alternative land cost used in the research.

The value of production per hectare measured gross return (GR) in November $2011\left(\mathrm{R} \$ 1.50 \mathrm{~kg}^{-1}\right)$ and July $2012\left(\mathrm{R} \$ 1.60 \mathrm{~kg}^{-1}\right)$. The net return (NR) calculated by the difference between the gross return (GR) per hectare and the total costs (TC) involved in obtaining it. The TC was calculated for each treatment, taking into account the input cost coefficients and the services used in one hectare of experimental lettuce. The rate of return (RR) was obtained from the relationship between GR and TC, corresponding to how many is received for each real applied in lettuce cultivation as a function of the used treatment factor. The net profit margin (NPM) consisted of the relationship between NR and GR, expressed as a percentage (BEZERRA NETO et al., 2010).

For each cropping season, an analysis of variance for the characteristics evaluated was performed using the SISVAR application (FERREIRA, 2011). A joint analysis was performed for the characteristic(s) with homogeneity of variances between the growing seasons. The adjustment procedure of response curves was carried out between variables and quantitative factors. The Tukey test $(p<0.05)$ was used to compare the means of the qualitative treatment.

\section{RESULTS AND DISCUSSION}

\section{Analysis of variance (joint analysis)}

From the results of the joint analysis of the variables evaluated as a function of the growing season, the amount of $C$. procera biomass and its incorporation time into the soil, it was observed that there was an interaction between the three factors for yield of green mass, gross return, net return and rate of return (Table 1).

Table 1. Summary of the joint analysis of variance (F values) for green mass yield (GMY), gross return (GR), net return (NR) and rate of return (RR) in the production of one hectare of lettuce fertilized with Calotropis procera, in two growing seasons.

\begin{tabular}{lcrrrr}
\hline & & \multicolumn{2}{c}{$\mathrm{F}$} \\
\cline { 3 - 6 } \multicolumn{1}{c}{ Sources of variation } & DF & \multicolumn{1}{c}{ GMY } & GR & \multicolumn{1}{c}{ NR } & RR \\
\hline Blocks (Season) & 4 & $3.14^{*}$ & $3.10^{*}$ & $3.10^{*}$ & $3.41^{*}$ \\
Season (S) & 1 & $1,609.98^{* *}$ & $1,166.17^{* *}$ & $1,567.83^{* *}$ & $2,222.14^{* *}$ \\
Amounts (A) & 3 & $320.78^{* *}$ & $310.65^{* *}$ & $220.94^{* *}$ & $160.80^{* *}$ \\
Times (T) & 3 & $380.71^{* *}$ & $365.64^{* *}$ & $365.64^{* *}$ & $399.92^{* *}$ \\
S x A & 3 & $5.31^{* *}$ & $4.06^{*}$ & $4.45^{* *}$ & $4.13^{* *}$ \\
S x T & 3 & $87.94^{* *}$ & $81.03^{* *}$ & $81.03^{* *}$ & $96.80^{* *}$ \\
A x T & 9 & $18.72^{* *}$ & $18.22^{* *}$ & $18.22^{* *}$ & $14.71^{* *}$ \\
S x A x T & 9 & $5.88^{* *}$ & $5.73^{* *}$ & $5.73^{* *}$ & $5.61^{*}$ \\
\hline CV (\%) & 9.74 & 5.86 & 11.71 & 18.76 \\
\hline Mean & & 19.46 & $29,932.17$ & $14,980.05$ & 1.81 \\
\hline
\end{tabular}

$\mathrm{ns}, * *$ and $*$ : significant at the $1 \%$ and $5 \%$ probability levels, by the $\mathrm{F}$ test, respectively. $\mathrm{DF}=$ degrees of freedom. $\mathrm{CV}=$ coefficient variation.

For the green lettuce mass yield, it was verified that maximum values were observed when fertilized with $15.6 \mathrm{t} \mathrm{ha}^{-1}$ of $C$. procera at the incorporation times of 11 (spring) and 15 (fallwinter) days before the crop was transplanted, reaching estimated yields of $39.61 \mathrm{t} \mathrm{ha}^{-1}$ in the first growing season and $25.94 \mathrm{t} \mathrm{ha}^{-1}$ in the second (Figure 2). Probably, the increase in the amount of C. procera allowed a higher availability of the macro and micronutrients in its composition, promoting improvements in soil fertility and microbial flora
(BATISTA et al., 2013, 2016). Concerning the better incorporation times, which were different between the growing seasons, it can be inferred that the mineralization of the green manure in the spring was faster than in the fall-winter, mainly due to the occurrence of higher temperatures during the spring planting (Figure 1). The meteorological conditions also showed the adaptability of lettuce cv. Babá-deVerão for production in environments of high temperatures and luminosity. 
A.

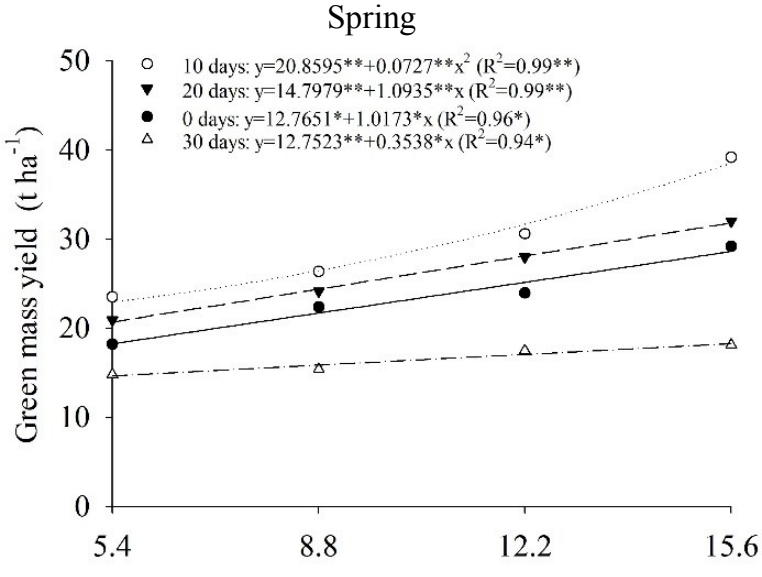

Amounts of C. procera biomass $\left(\mathrm{t} \mathrm{ha}^{-1}\right)$

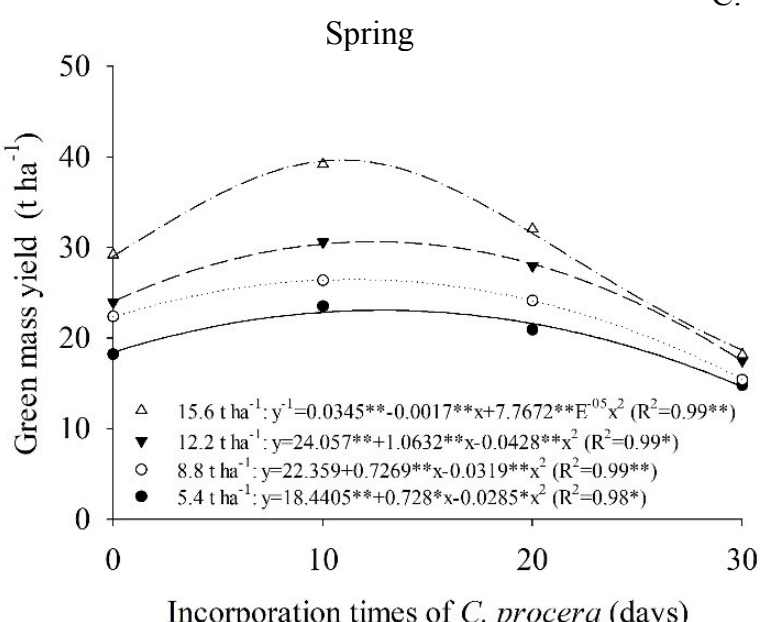

B.

Fall-winter

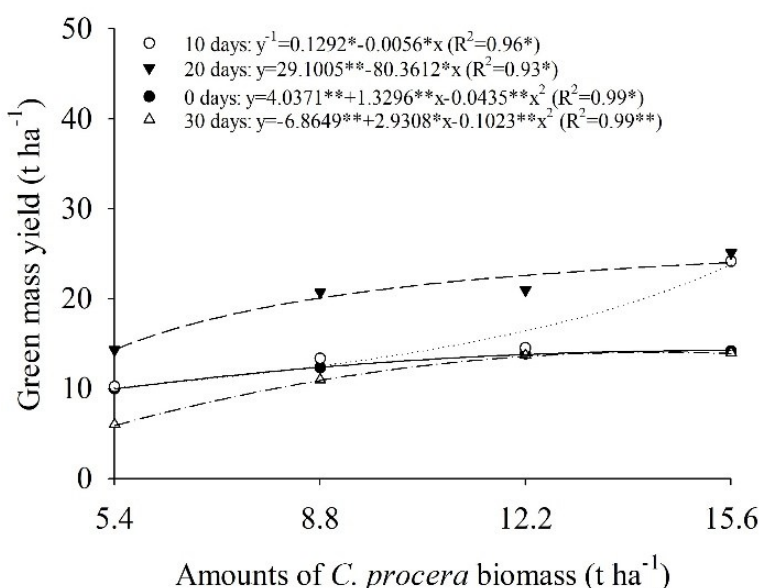

D.

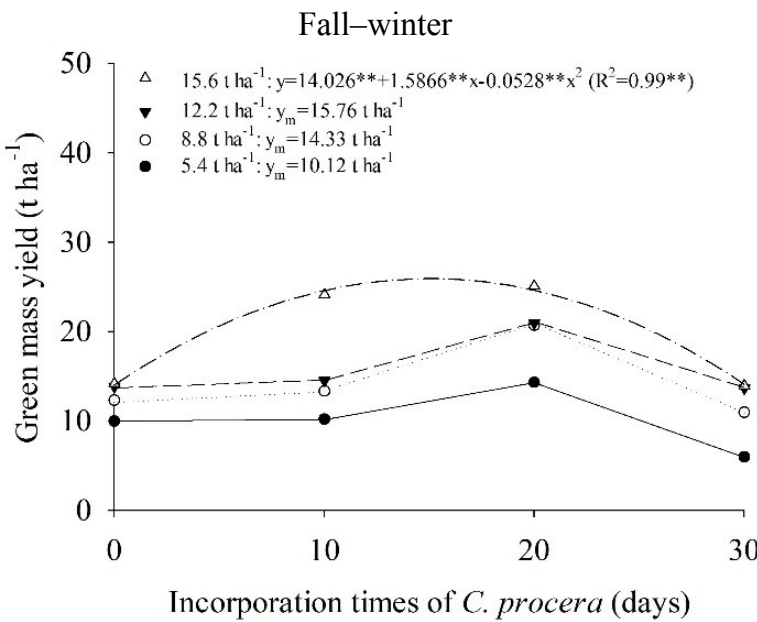

Figure 2. Green mass yield $\left(\mathrm{t} \mathrm{ha}^{-1}\right)$ of lettuce fertilized with Calotropis procera as a function of the interaction of the amounts and the incorporation times of the green manure (A. spring; B. fall-winter), within each season of cultivation, and reverse unfolding (C. spring, D. fall-winter).

Since the price paid for lettuce did not vary between growing seasons ( $\mathrm{R} \$ 1.50$ to $\mathrm{R} \$ 1.60)$, the gross return results had similar statistical behavior to that observed for green mass yield (Figure 3), that is, the cultivation of spring was more favorable to the development of lettuce, with the amount of $15.6 \mathrm{tha}^{-}$ ${ }^{1}$ of green manure associated with the time of 11 days reaching maximum gross return of $R \$$ $58,183.72 \mathrm{ha}^{-1}$, which was considered superior to the best combination of factors in fall-winter, whose income was estimated at $\mathrm{R} \$ 41,508.18 \mathrm{ha}^{-1}$ at the dose of $15.6 \mathrm{t} \mathrm{ha}^{-1}$ of C. procera, incorporated 15 days before transplanting vegetables (Figure 3 ). 
A.

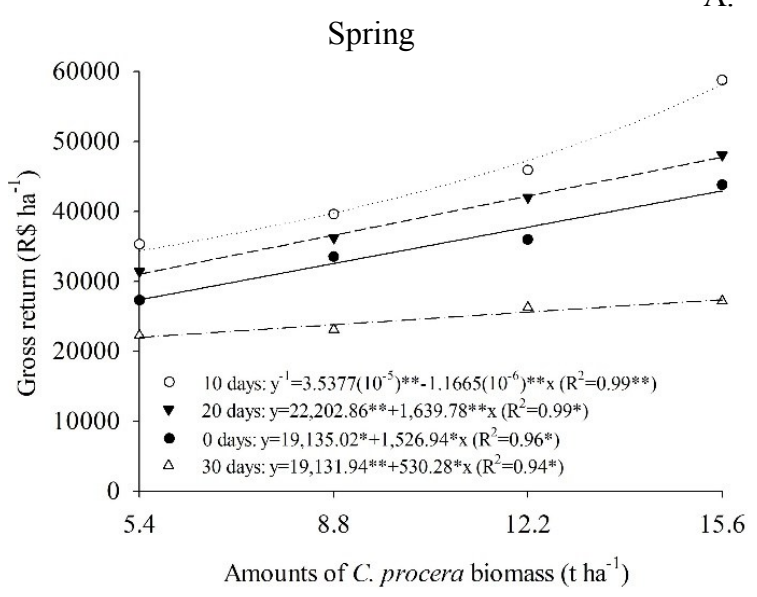

C.

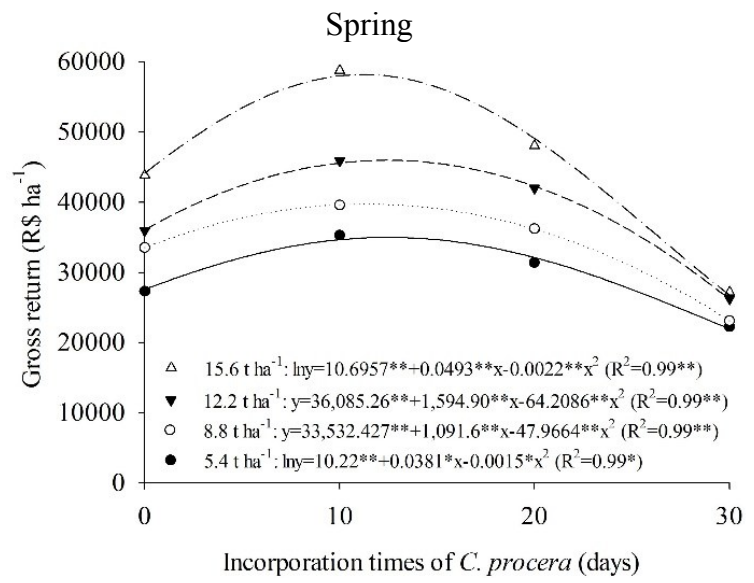

B.

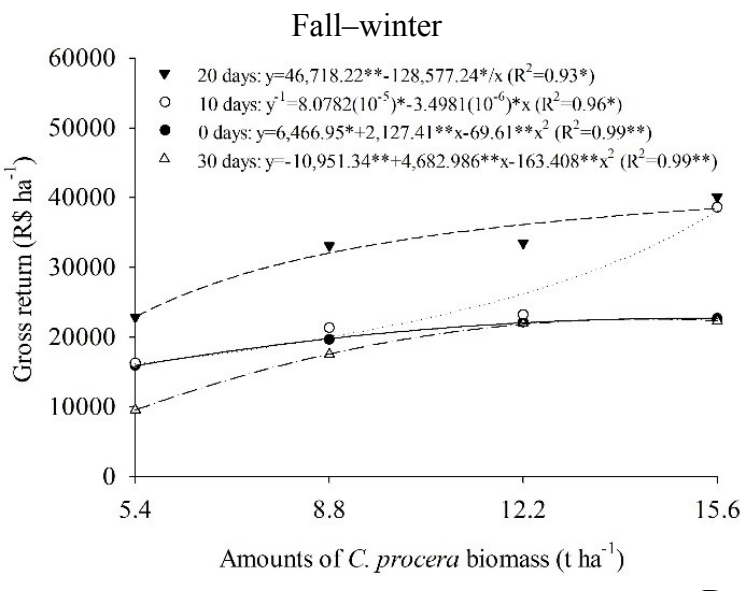

D.

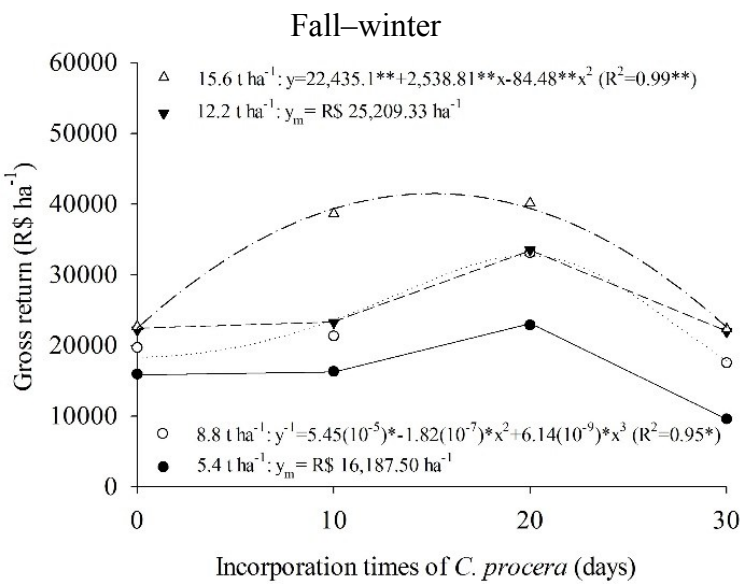

Figure 3. Gross return $\left(\mathrm{R} \$ \mathrm{ha}^{-1}\right)$ of lettuce fertilized with Calotropis procera as a function of the interaction of the amounts and the incorporation times of the green manure (A. spring; B. fall-winter), within each growing season, and reverse unfolding (C. spring, D. fall-winter).

Positive effects of green manuring with spontaneous Caatinga species were also found by Oliveira et al. (2015) and Souza et al. (2015) in arugula cultivation, where they observed an increase in gross return with increasing doses of $C$. procera, reaching a gross return of $\mathrm{R} \$ 40,622.48 \mathrm{ha}^{-1}$ and $\mathrm{R} \$ 69,492.65$ $\mathrm{ha}^{-1}$, respectively, in the higher doses applied. These results demonstrate the importance of using C. procera as green manure because it increased the gross return of lettuce through benefits provided by the higher availability of nutrients and the retention of water in the soil.
Table 2 shows the sum of variable, fixed and opportunity costs, which varied between $\mathrm{R} \$$ 11,836.60 $\mathrm{ha}^{-1}$ (spring) and $\mathrm{R} \$ 13,392.60 \mathrm{ha}^{-1}$ (fallwinter). The total cost of producing one hectare of lettuce fertilized with $C$. procera was estimated for each quantity incorporated into the soil of the green manure $\left(5.4,8.8,12.2\right.$ and $\left.15.6 \mathrm{t} \mathrm{ha}^{-1}\right)$, and the following amounts were verified, respectively: $\mathrm{R} \$$ $12,916.10 ; \mathrm{R} \$ 13,622.44 ; \mathrm{R} \$ 14,331.30$ and $\mathrm{R} \$$ $15,037.66$ for the spring crop, and $\mathrm{R} \$ 14,673.60 ; \mathrm{R} \$$ $15,508.44$; $\mathrm{R} \$ 16,346.30$ and $\mathrm{R} \$ 17,181.16$ for the fall-winter crops (Table 3). 
Ê. G. F. SOUZA et al.

Table 2. Coefficients of variable, fixed and opportunity costs in the production of one hectare of lettuce according to the growing seasons.

\begin{tabular}{|c|c|c|c|c|}
\hline \multirow[b]{2}{*}{ Components of Production Costs } & \multirow[b]{2}{*}{ Unit } & \multirow[b]{2}{*}{ Quantity } & \multicolumn{2}{|c|}{ Total (R\$) } \\
\hline & & & Spring & Fall-winter \\
\hline Variable costs & & & $9,160.60$ & $10,562.60$ \\
\hline 1 - Inputs & & & $3,870.00$ & $4,257.00$ \\
\hline Seeds: Lettuce cv. Babá-de-Verão & $\mathrm{kg}$ & 2.5 & 300.00 & 330.00 \\
\hline Commercial substrate: Plantmax HT® & $25 \mathrm{~kg}$ & 170 & $3,570.00$ & $3,927.00$ \\
\hline $2-$ Labor & & & $5,075.00$ & $6,090.00$ \\
\hline Manufacture of beds & daily & 40 & $1,000.00$ & $1,200.00$ \\
\hline Filling trays & daily & 20 & 500.00 & 600.00 \\
\hline Sowing lettuce & daily & 30 & 750.00 & 900.00 \\
\hline Roughing of lettuce & daily & 20 & 500.00 & 600.00 \\
\hline Transplanting lettuce & daily & 30 & 750.00 & 900.00 \\
\hline Hand weeding & daily & 5 & 125.00 & 150.00 \\
\hline Irrigation & daily & 15 & 375.00 & 450.00 \\
\hline Harvest of lettuce & daily & 40 & $1,000.00$ & $1,200.00$ \\
\hline Transport of lettuce & daily & 3 & 75.00 & 90.00 \\
\hline $3-$ Energy & & & 215.60 & 215.60 \\
\hline Energy used for irrigation & $\mathrm{kW}$ & 980.0 & 215.60 & 215.60 \\
\hline Fixed Costs & & & $2,276.00$ & $2,430.00$ \\
\hline $4-$ Depreciation & & & $1,176.00$ & $1,176.00$ \\
\hline Irrigation pump & month* & 2 & 115.00 & 115.00 \\
\hline Irrigation Pipes & month & 2 & 7.00 & 7.00 \\
\hline Connections & month & 2 & 26.00 & 26.00 \\
\hline 128-cell trays & month & 2 & 798.00 & 798.00 \\
\hline Micro Sprinklers & month & 2 & 80.00 & 80.00 \\
\hline Forage & month & 1 & 150.00 & 150.00 \\
\hline $5-$ Taxes & & & 10.00 & 10.00 \\
\hline Rural territorial tax & ha & 1 & 10.00 & 10.00 \\
\hline 6 - Fixed labor force & & & $1,090.00$ & $1,244.00$ \\
\hline Aux. Administrative & Salary & 2 & $1,090.00$ & $1,244.00$ \\
\hline Opportunity Costs & & & 400.00 & 400.00 \\
\hline $7-$ Remuneration by land & & & 200.00 & 200.00 \\
\hline Lease land & ha & 1 & 200.00 & 200.00 \\
\hline $8-$ Remuneration of fixed capital ( $0.5 \%$ per month) & & & 200.00 & 200.00 \\
\hline Infrastructure and equipment & $\mathrm{R} \$ 100.00$ month $^{-1 * *}$ & 2 & 200.00 & 200.00 \\
\hline Total (Variable + Fixed Costs + Opportunity) & & & $11,836.60$ & $13,392.60$ \\
\hline
\end{tabular}

*Relationship between the market value and the useful life of the equipment, multiplied by the time of use; **regarding the value of fixed capital $(\mathrm{R} \$ 20,000.00)$ multiplied by its remuneration over the crop. 
Ê. G. F. SOUZA et al.

Table 3. Total costs in the production of one hectare of lettuce according to the quantities of Calotropis procera and growing seasons.

\begin{tabular}{|c|c|c|c|c|}
\hline \multirow{2}{*}{ Components of Production Costs } & \multirow{2}{*}{ Unit } & \multirow{2}{*}{ Quantity } & \multicolumn{2}{|c|}{ Total (R\$) } \\
\hline & & & Spring & Fall-winter \\
\hline \multicolumn{5}{|l|}{$1-5.4 \mathrm{t} \mathrm{ha}^{-1}$ of Calotropis procera } \\
\hline Cutting & daily & 20.0 & 500.00 & 600.00 \\
\hline Transportation & freightage & 1.0 & 75.00 & 80.00 \\
\hline Crushing & daily & 2.5 & 62.50 & 75.00 \\
\hline Energy (forrage) & $\mathrm{kW}$ & 100 & 22.00 & 22.00 \\
\hline Drying & daily & 5.0 & 125.00 & 150.00 \\
\hline Bagging & daily & 1.0 & 25.00 & 30.00 \\
\hline Distribution and incorporation & daily & 10.8 & 270.00 & 324.00 \\
\hline Variable, fixed and opportunity costs & & & $11,836.60$ & $13,392.60$ \\
\hline Production cost for application of $5.4 \mathrm{t} \mathrm{ha}^{-1}$ & & & $12,916.10$ & $14,673.60$ \\
\hline \multicolumn{5}{|l|}{$2-8.8 \mathrm{t} \mathrm{ha}^{-1}$ of Calotropis procera } \\
\hline Cutting & daily & 32.6 & 815.00 & 978.00 \\
\hline Transportation & freightage & 2.0 & 150.00 & 160.00 \\
\hline Crushing & daily & 4.1 & 102.50 & 123.00 \\
\hline Energy (forrage) & $\mathrm{kW}$ & 162.9 & 35.84 & 35.84 \\
\hline Drying & daily & 8.1 & 202.50 & 243.00 \\
\hline Bagging & daily & 1.6 & 40.00 & 48.00 \\
\hline Distribution and incorporation & daily & 17.6 & 440.00 & 528.00 \\
\hline Variable, fixed and opportunity costs & & & $11,836.60$ & $13,392.60$ \\
\hline Cost of production for application of $8.8 \mathrm{t} \mathrm{ha}^{-1}$ & & & $13,622.44$ & $15,508.44$ \\
\hline \multicolumn{5}{|l|}{$3-12.2 \mathrm{t} \mathrm{ha}^{-1}$ of Calotropis procera } \\
\hline Cutting & daily & 45.2 & $1,130.00$ & $1,356.00$ \\
\hline Transportation & freightage & 3.0 & 225.00 & 240.00 \\
\hline Crushing & daily & 5.6 & 140.00 & 168.00 \\
\hline Energy (forrage) & $\mathrm{kW}$ & 225.9 & 49.70 & 49.70 \\
\hline Drying & daily & 11.3 & 282.50 & 339.00 \\
\hline Bagging & daily & 2.3 & 57.50 & 69.00 \\
\hline Distribution and incorporation & daily & 24.4 & 610.00 & 732.00 \\
\hline Variable, fixed and opportunity costs & & & $11,836.60$ & $13,392.60$ \\
\hline Cost of production for application of $12.2 \mathrm{t} \mathrm{ha}^{-1}$ & & & $14,331.30$ & $16,346.30$ \\
\hline \multicolumn{5}{|l|}{$4-15.6 \mathrm{t} \mathrm{ha}^{-1}$ of Calotropis procera } \\
\hline Cutting & daily & 57.8 & $1,445.00$ & $1,734.00$ \\
\hline Transportation & freightage & 4.0 & 300.00 & 320.00 \\
\hline Crushing & daily & 7.2 & 180.00 & 216.00 \\
\hline Energy (forrage) & $\mathrm{kW}$ & 288.9 & 63.56 & 63.56 \\
\hline Drying & daily & 14.4 & 360.00 & 432.00 \\
\hline Bagging & daily & 2.9 & 72.50 & 87.00 \\
\hline Distribution and incorporation & daily & 31.2 & 780.00 & 936.00 \\
\hline Variable, fixed and opportunity costs & & & $11,836.60$ & $13,392.60$ \\
\hline Cost of production for application of $15.6 \mathrm{t} \mathrm{ha}^{-1}$ & & & $15,037.66$ & $17,181.16$ \\
\hline
\end{tabular}

Activities ranging from harvesting to the preparation of green manure were responsible for $8.5,13.4,17.7$ and $21.6 \%$ of the total costs related to increasing amounts of $C$. procera $(5.4,8.8,12.2$ and $15.6 \mathrm{t} \mathrm{ha}^{-1}$ ), respectively (Table 3 ). Labor costs corresponded on average to 49.8 (spring) and 52.5\% (fall-winter) of the total costs of each treatment in the cultivation of lettuce fertilized with $C$. procera). These results are somewhat lower than those found by Araújo Neto, Ferreira and Pontes (2009) in the organic production of lettuce and by Barros Júnior et al. (2008) in conventional lettuce production, in which both also observed that the most expensive costs are labor costs, corresponding to $78.8 \%$ and 53.3\% (crisp lettuce) and 60.1\% (American lettuce), respectively. In the case of the employment of family labor, these costs are considered as income to the farmers themselves.
Between the growing seasons, the cost became higher in the fall and winter, mainly due to the readjustment in the daily price paid to the rural worker (from R\$ 25.00 to $\mathrm{R} \$ 30.00$ ). It should be noted that the difference in cost of production is related to the costs of cutting, transport, crushing, electric energy of the forage, drying, bagging, distribution and incorporation of $C$. procera, with differences between expenses, which increased according to the amount of biomass of the green manure.

Evaluating different amounts of $C$. procera and their time of incorporation to the soil in the production of one hectare of arugula, Souza et al. (2015) reached lower production costs compared to the present research, with values of $\mathrm{R} \$ 6,705.08, \mathrm{R} \$$ $7,406.42, \mathrm{R} \$ 8,110.28$ and $\mathrm{R} \$ 8,811.64$ for the spring-summer crop, and $\mathrm{R} \$ 7,628.60, \mathrm{R} \$ 8,463.44$, 
$\mathrm{R} \$ 9,301.30$ and $\mathrm{R} \$ 10,136.16$ in the fall, for the amounts of $5.4,8.8,12.2$ and $15.6 \mathrm{t} \mathrm{ha}{ }^{-1}$, respectively. This difference is a result of the additional costs of lettuce seedling production.

From the difference between gross return and total production costs, there was a net return from production, which reached a maximum of $\mathrm{R} \$$ 43,940.08 $\mathrm{ha}^{-1}$ (spring) and R\$ 24,327.02 $\mathrm{ha}^{-1}$ (fallwinter), associated with fertilization with $15.6 \mathrm{tha}^{-1}$ and incorporation times of 11 and 15 days before lettuce transplanting, respectively (Figure 4). The

A.
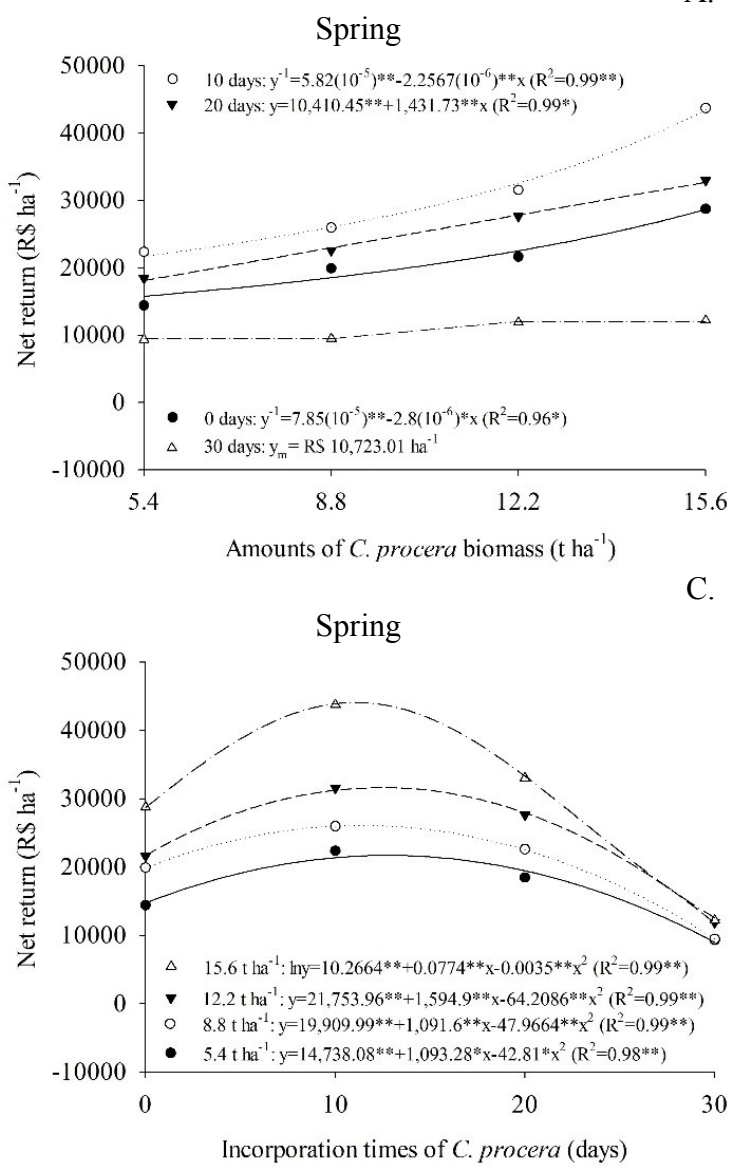

superiority of net return in spring results from the gross return on investment in this growing season ( $\mathrm{R} \$ 58,183.72 \mathrm{ha}^{-1}$ ), which was about $40 \%$ higher than the gross return of the best fall-winter treatment $\left(\mathrm{R} \$ 41,508.18 \mathrm{ha}^{-1}\right)$. Besides, spring production costs were $14.2 \%$ lower than in the fall and winter, contributing to an increase in net return. According to Bezerra Neto et al. (2012), the net profit better expressed the economic value than the gross return, because the costs of production are deducted from them.

B.

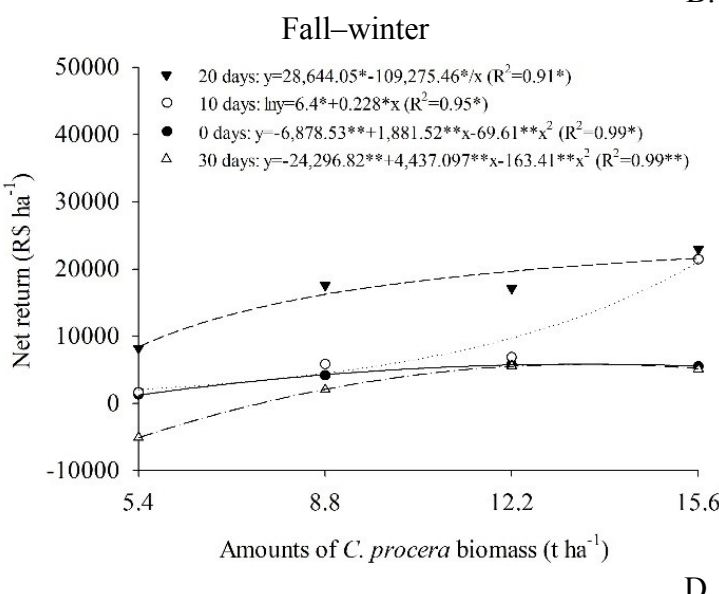

D.

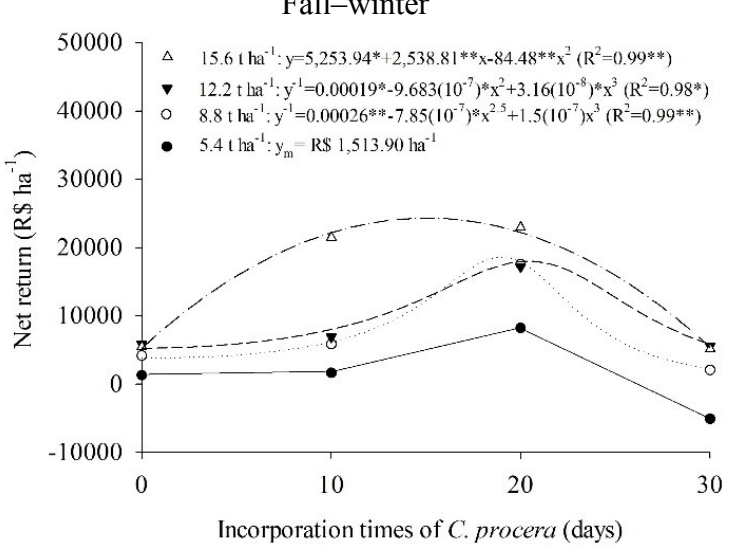

Figure 4. Net return $\left(\mathrm{R} \$ \mathrm{ha}^{-1}\right)$ of lettuce fertilized with Calotropis procera as a function of the interaction of the amounts and the incorporation times of the green manure (A. primavera; B. fall-winter), within each growing season, and reverse unfolding (C. spring, D. fall-winter).

Silva et al. (2015), working with green fertilization with $C$. procera on radish cultivation, observed results similar to the present research, in which there was an increasing behavior of net return as a function of the biomass amounts of C. procera, reaching the maximum values of $\mathrm{R} \$ 34,845.85 \mathrm{ha}^{-1}$ (spring-summer) and $\mathrm{R} \$ 35,330.49 \mathrm{ha}^{-1}$ (fall-winter) at a dose of $15.6 \mathrm{tha}^{-1}$. On the other hand, Oliveira et al. (2015) obtained a higher net return of $\mathrm{R} \$$ $30,091.04 \mathrm{ha}^{-1}$ when they fertilized arugula plants with $70.0 \mathrm{t} \mathrm{ha}^{-1}$ of $C$. procera, in a low soil fertility condition in the experimental area. These results also demonstrated the feasibility of using $C$. procera biomass, but indicate that the amounts should be adjusted according to the vegetable to be produced and the current condition of soil fertility.

In spring, the highest rate of return ( $\mathrm{R} \$ 3.95)$ was obtained with the use of $15.6 \mathrm{t} \mathrm{ha}^{-1}$ of $C$. procera added to the soil 11 days before lettuce transplanting (Figures 5A and 5C), corresponding to an increase of $124.4 \%$ in relation to the lower result of this growing period. In the fall-winter period, the $15.6 \mathrm{t} \mathrm{ha}^{-1}$ dose of green manure in the 15-day period had a maximum estimated rate of return of $R \$ 2.41$ per 
invested real (Figure 5D). In both growing seasons, yields of green lettuce mass in the above treatment combinations provided high gross returns, which offset the investment in the largest amount of green manure, whose production, preparation and incorporation costs were $196 \%$ higher.

Rezende et al. (2009) evaluated the yield of several vegetables in single and intercropping cultivation systems and observed a return rate of 7.46 in single lettuce cultivation, which is considered elevated when compared to the current research, mainly due to the reduced costs of seedling production and chemical fertilization. Although the rate of return is lower, this does not invalidate the adoption of green manure as a cultural practice in the production of lettuce, since it presented a rate higher than 1.0, which represents a profit from investment (BATISTA et al., 2013, 2016), making it more sustainable in the medium and long-term. In addition, the sustainable cultivation of vegetables allows access to specific markets, where products can become more valued.

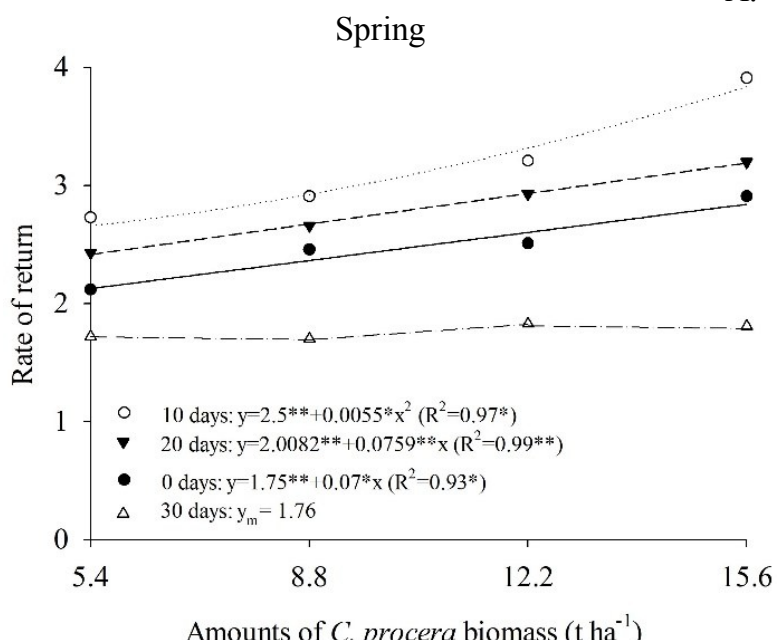

Amounts of $C$. procera biomass $\left(\mathrm{t} \mathrm{ha}^{-1}\right)$

Spring

C.

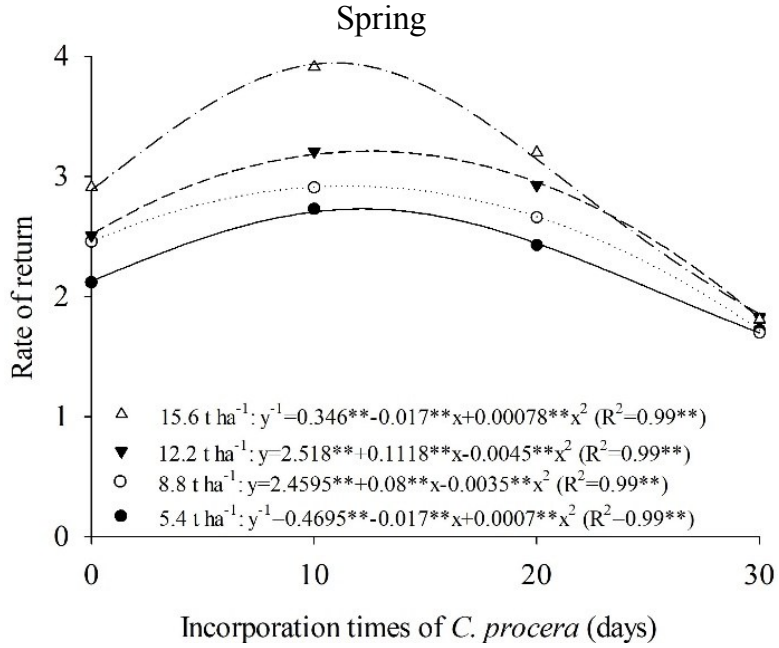

B.

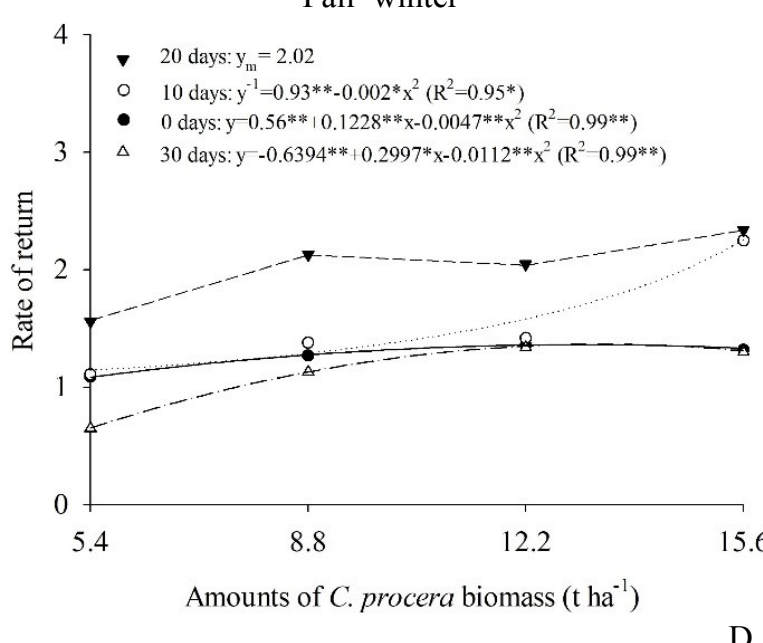

Fall-winter

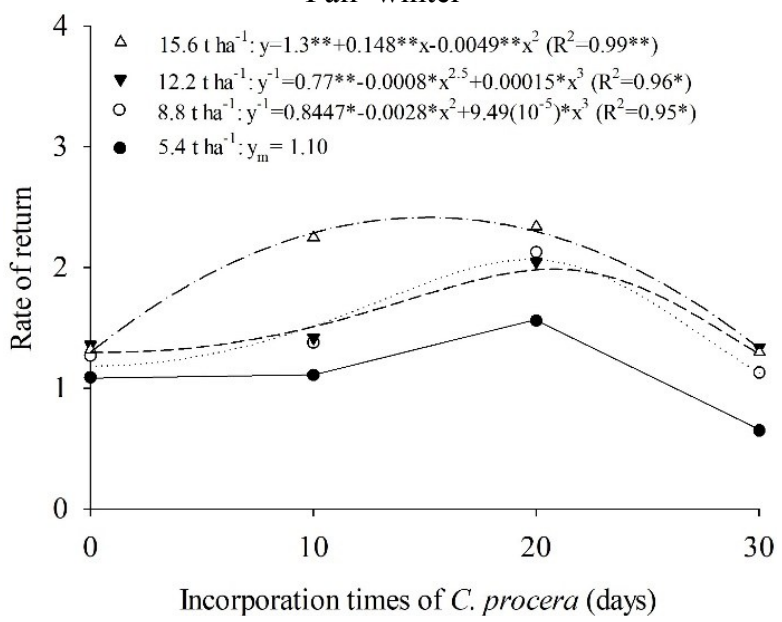

Figure 5. Rate of return of one hectare of lettuce fertilized with Calotropis procera as a function of the interaction of the amounts and the incorporation times of the green manure (A. spring, B. fall-winter), within each growing season, and reverse unfolding (C. spring, D. fall-winter).

\section{Analysis of individual variance}

Individual variance analysis of the net profit margin revealed that no variance homogeneity was observed between growing seasons. In this way, the analysis of variance of each experiment was performed. There was an interaction between the amounts and the time of incorporation of $C$. procera in the two growing seasons (Table 4). 
Ê. G. F. SOUZA et al.

Table 4. Summary of the individual analysis of variance (F values) for net profit margin (NPM) in the yield of one hectare of lettuce fertilized with Calotropis procera in two growing seasons.

\begin{tabular}{lccc}
\hline & & & NPM \\
\cline { 3 - 4 } \multicolumn{1}{c}{ Sources of variation } & DF & Spring & Fall-winter \\
\hline Blocks & 2 & $3.05^{\text {ns }}$ & $2.90^{\text {ns }}$ \\
Amounties & 3 & $70.37^{* *}$ & $53.07^{* *}$ \\
Times & 3 & $529.16^{* *}$ & $67.91^{* *}$ \\
Quantities x Times & 9 & $4.51^{* *}$ & $9.46^{* *}$ \\
\hline CV (\%) & & 2.79 & 34.11 \\
\hline Mean & & 58.65 & 24.89 \\
\hline
\end{tabular}

ns and **: nonsignificant and significant at the $1 \%$ probability level, by the $\mathrm{F}$ test, respectively. $\mathrm{DF}=$ degrees of freedom. $\mathrm{CV}=$ coefficient variation.

In spring, the amount of $15.6 \mathrm{t} \mathrm{ha}^{-1}$ of $C$. procera, together with the incorporation of green manure 11 days before lettuce transplanting, promoted a maximum net profit margin of $75.0 \%$ (Figure 6A and 6B). It is important to note that, regardless of the factors (quantity or incorporation time), the yield of the lettuce crop in the spring was higher than $40 \%$, demonstrating the agronomic and economical viability of the sustainable production of this vegetable. The use of the lower dose of $C$. procera during this growing season would be an alternative for the less capitalized farmer, allowing profitability compatible with the investment made. Bezerra Neto, Gomes and Oliveira (2007) reached a net profit margin of $68.8 \%$ in conventional lettuce cultivation in the semi-arid region of Potiguar, Brazil, indicating that the green manure with $C$. procera can also be a profitable alternative to the rural producer.

In fall-winter, it can be observed that the net profit margin varied little between the biomass amounts of $C$. procera and the incorporation time of 20 days before lettuce transplanting (Figure 6C). According to Figure 6D, lettuce yields were higher when applied $15.6 \mathrm{t} \mathrm{ha}^{-1}$ and 15 days $(60.1 \%)$ than the treatments with $8.8 \mathrm{t} \mathrm{ha}^{-1}$ and 19 days (54.3\%); $12.2 \mathrm{t} \mathrm{ha}^{-1}$ and 20 days (50.8\%) and $5.4 \mathrm{t} \mathrm{ha}^{-1}$ and 20 days $(35.9 \%)$. Although it did not influence the production costs, the incorporation time of the green manure was determinant for a satisfactory and positive economic return of the lettuce produced in fall and winter, because the synchrony between the release of the nutrients present in $C$. procera and the period of nutritional requirement of the crop is reflected in higher productivity for lettuce, with a consequent increase in the net profit margin.

Some previous studies found net profit margins close to the present research. Studying green manure with $C$. procera on the cultivation of beetroot (BATISTA, 2011), radish (SILVA et al., 2015) and arugula (SOUZA et al., 2015; OLIVEIRA et al., 2015), and with Merremia aegyptia L. (scarlet starglory) in carrot culture (OLIVEIRA et al., 2012; BEZERRA NETO et al., 2014), the researchers demonstrated the agro-economic feasibility of green manure with spontaneous of the Caatinga species in leafy and root crops.

In general, these results indicate that lettuce responds very well to green manure with $C$. procera, reflecting the yield of green mass and the profitability of the investment tied to a reduced production cost. In addition, sustainable cultivation allows better use of local environmental resources, reducing dependence on external inputs.

Production costs can be reduced by using family labor for cultivating and preparing green manure on the farm itself, thus reducing transportation costs. In this way, the farmer, even with few resources to invest in the activity, can increase the yield of the crop through a locally available and easily renewable fertilizer, because $C$. procera has high potential for regrowth (ANDRADE et al., 2008). In addition, this green manure is conserved in the form of hay (SILVA et al., 2010; SILVA et al., 2012), favoring its storage for several years, without prejudice to its nutritional qualities. 
A.

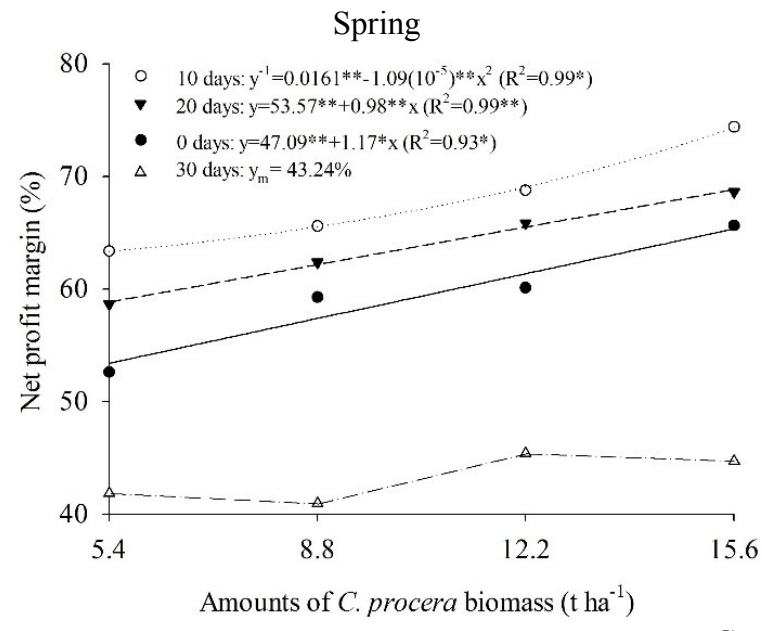

Fall-winter

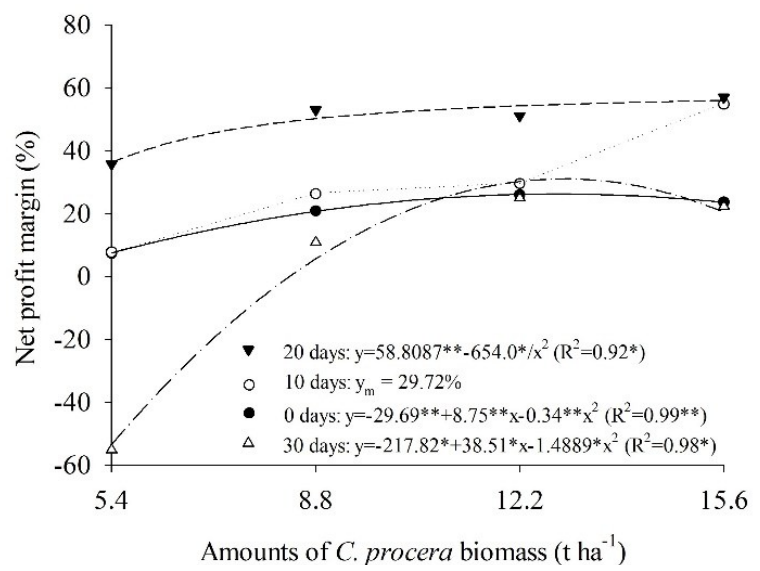

B.

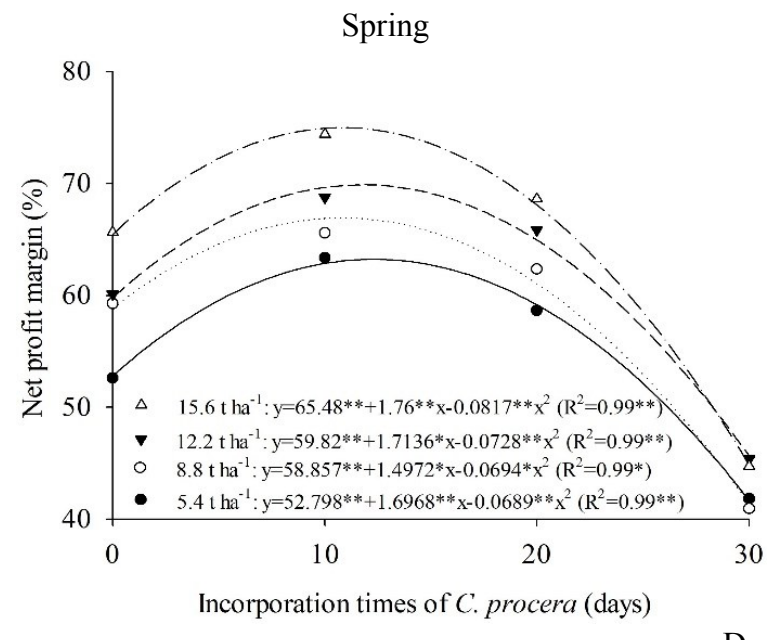

Fall-winter

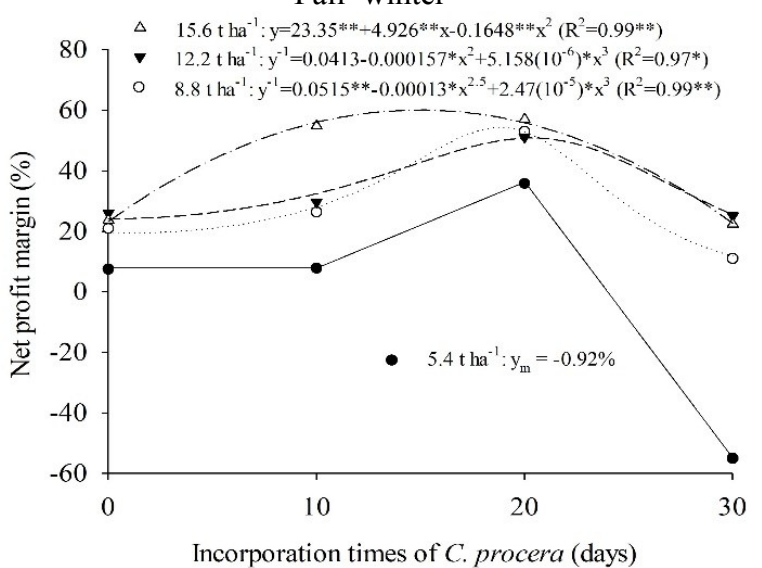

Figure 6. Net profit margin (\%) of one hectare of lettuce fertilized with Calotropis procera as a function of the interaction of the amounts and the incorporation times of green manure in spring (A and B) and fall-winter (C and D).

\section{CONCLUSIONS}

The best economic performance of lettuce cv. Babá-de-Verão was obtained via green manure in the form of $15.6 \mathrm{t} \mathrm{ha}^{-1}$ of $C$. procera.

The ideal incorporation time of the green manure was 11 (spring) and 15 (fall-winter) days before transplanting the lettuce seedlings.

Cultivation in the spring promoted a higher economic return to the production of lettuce fertilized with $C$. procera.

\section{REFERENCES}

ANDRADE, M. V. M. et al. Produtividade e qualidade da Flor-de-seda em diferentes densidades e sistemas de plantio. Revista Brasileira de Zootecnia, v. 37, n. 1, p. 1-8, 2008.

ARAÚJO NETO, S. E.; FERREIRA, R. L. F.; PONTES, F. S. Rentabilidade da produção orgânica de cultivares de alface com diferentes preparos do solo e ambiente de cultivo. Ciência Rural, v. 39, n.
5, p. 1362-1368, 2009.

BARROS JÚNIOR, A. P. et al. Custo de produção e rentabilidade de alface crespa e americana em monocultura e quando consorciada com rúcula. Revista Caatinga, v. 21, n. 2, p. 181-192, 2008.

BATISTA, M. A. V. Adubação verde na produtividade, qualidade e rentabilidade de beterraba e rabanete. 2011. $123 \mathrm{f}$. Tese (Doutorado em Fitotecnia: Área de Concentração em Agricultura Tropical) - Universidade Federal Rural do SemiÁrido, Mossoró, 2011.

BATISTA, M. A. V. et al. Atributos microbiológicos do solo e produtividade de rabanete influenciados pelo uso de espécies espontâneas. Horticultura Brasileira, v. 31, n. 4, p. 587-594, 2013.

BATISTA, M. A. V. et al. Atributos de solo-planta e de produção de beterraba influenciados pela adubação com espécies da Caatinga. Horticultura Brasileira, v. 34, n. 1, p. 31-38, 2016. 
BEZERRA NETO, F. et al. Otimização agroeconômica da cenoura fertilizada com diferentes doses de jitirana. Revista Ciência Agronômica, v. 45 , n. 2 , p. $305-311,2014$

BEZERRA NETO, F. et al. Evaluation of yield advantage indexes in carrot-letucce intercroppinh systems. Interciencia, v. 35, n. 1, p. 59-64, 2010.

BEZERRA NETO, F.; GOMES, E. G.; OLIVEIRA, A. M. Produtividade biológica em sistemas consorciados de cenoura e alface avaliada através de indicadores agroeconômicos e métodos multicritério. Horticultura Brasileira, v. 25, n. 2, p. 193-198, 2007.

BEZERRA NETO, $F$. et al. Assessment of agroeconomic indices in polycultures of lettuce, rocket and carrot through uni- and multivariate approaches in semi-arid Brazil. Ecological Indicators, v. 14, n. 1, p. 11-17, 2012.

CARVALHO, J. B.; SABBAG, O. J. Análise de eficiência da produção de alface no noroeste de São Paulo. Revista Agro@mbiente On-line, v. 9, n. 2, p. 152-160, 2015.

CENTRO DE PESQUISAS AMBIENTAIS DO NORDESTE - CEPAN. Contextualização sobre espécies exóticas invasoras. 2009. Disponível em: $<$ http://www.avesmarinhas.com.br/10\%20-\% 20Contextualiza $\% \mathrm{C3} \% \mathrm{~A} 7 \% \mathrm{C3} \% \mathrm{~A} 30 \% 20$ Sobre $\%$ $20 \mathrm{Esp} \% \mathrm{C} 3 \%$ A 9 cies $\% 20 \mathrm{Ex} \% \mathrm{C} 3 \%$ B3ticas $\%$ 20Invasoras.pdf $>$. Acesso em: 20 abr. 2017.

ESPINDOLA, J. A. A.; ALMEIDA, D. L.; GUERRA, J. G. M. Estratégias para utilização de leguminosas para adubação verde em unidades de produção agroecológica. Seropédica, RJ: Embrapa Agrobiologia, 2004. 24 p. (Documentos, 174).

FERREIRA, D. F. Sisvar: a computer statistical analysis system. Ciência e Agrotecnologia, v. 35, n. 6, p. 1039-1042, 2011.

LINHARES, P. C. F. et al. Roostertree (Calotropis procera) under different amounts and periods of incorporation on yield of coriander. Revista Verde, v. 9, n. 3 , p. $7-12,2014$.

LINHARES, P. C. F. et al. Velocidade de decomposição da Flor-de-seda no desempenho agronômico da Rúcula cv. Cultivada. Revista Verde, v. 4, n. 2, p. 46-50, 2009.

MAROUELLI, W. A.; SILVA, W. L. C.; SILVA, H. R. Irrigação por aspersão em hortaliças. 2. ed. rev. atual. ampl. Brasília, DF: Embrapa Informação Tecnológica, 2008. 150 p.
MONTEMURRO, F. et al. Anaerobic digestate and on-farm compost application: effects on lettuce (Lactuca sativa L.) crop production and soil properties. Compost Science \& Utilization, v. 18, n. 3, p. 184-193, 2010.

OLIVEIRA, L. A. A. et al. Produção agroeconômica da rúcula fertilizada com diferentes quantidades de Calotropis procera. Revista Terceiro Incluído, v. 5, n. 2, p. 373-384, 2015.

OLIVEIRA, M. K. T. et al. Desempenho agroeconômico da cenoura adubada com jitirana (Merremia aegyptia). Horticultura Brasileira, v. 30, n. 3, p. 433-439, 2012.

OLIVEIRA, M. K. T. et al. Desempenho agronômico da cenoura adubada com jitirana antes de sua semeadura. Revista Ciência Agronômica, v. 42, n. 2, p. 364-372, 2011

REZENDE, B. L. A. et al. Custo de produção e rentabilidade das culturas de alface, rabanete, rúcula e repolho em cultivo solteiro e consorciadas com pimentão. Ciência e Agrotecnologia, v. 33, n. 1, p. 305-312, 2009.

SILVA, A. F. A. et al. Desempenho agronômico do rabanete adubado com Calotropis procera (Ait.) $\mathrm{R}$. Br. em duas épocas de cultivo. Revista Ciência Agronômica, v. 48, n. 2, p. 328-336, 2017.

SILVA, A. F. A. et al. Rentabilidade do rabanete adubado com flor-de-seda em duas épocas de cultivo no semiárido de Pernambuco. Revista de Ciências Agrárias, v. 58, n. 2, p. 198-207, 2015.

SILVA, F. C. Manual de análises químicas de solos, plantas e fertilizantes. 2. ed. rev. ampl. Brasília, DF: Embrapa Informação Tecnológica, 2009. $627 \mathrm{p}$.

SILVA, J. G. M. et al. Cactáceas nativas associadas a fenos de flor de seda e sabiá na alimentação de borregos. Revista Caatinga, v. 23, n. 3, p. 123-129, 2010 .

SILVA, N. V. et al. Efeito do feno de flor-de-seda sobre a carcaça e constituintes corporais de cordeiros Morada Nova. Archivos de Zootecnia, v. 61, n. 233, p. 63-70, 2012.

SOUTO, P. C. et al. Biometria de frutos e numero de sementes de Calotropis procera (Ait.) R. Br. no semi -árido da Paraiba. Revista Verde, v. 3, n. 1, p. 108113,2008 
SOUZA, C. M. et al. Adubação verde e rotação de culturas. Viçosa, MG: UFV, 2012. 108 p.

SOUZA, Ê. G. F. et al. Rentabilidade da rúcula fertilizada com biomassa de Flor-de-seda em função da época de cultivo. Revista Caatinga, v. 28, n. 1, p. 65-77, 2015.

SOUZA, Ê. G. F. et al. Production of lettuce under green manuring with Calotropis procera in two cultivation seasons. Revista Caatinga, v. 30, n. 2, p. 391-400, 2017. 